\title{
Identifikasi Pemahaman Guru Tentang Pengembangan Perangkat Pembelajaran IPA SMP dengan Pendekatan Etnosain
}

\author{
Yayuk Andayani*, Agus Abhi Purwoko, Jamaluddin, \\ Muh. Makhrus, Ahmad Harjono
}

Program Studi Magister Pendidikan IPA, Pascasarjana Universitas Mataram, Indonesia

\begin{abstract}
Kata Kunci:
Pengembangan

perangkat,

Pembelajaran

IPA, SMP,

Etnosain

Abstrak: Tujuan pengabdian masyarakat ini untuk meningkatkan pemahaman guru IPA SMP dalam pengembangan perangkat pembelajaran IPA dengan pendekatan etnosains. Pemahaman guru diperoleh melalui pelatihan dengan sasaran guru-guru IPA dari 20 SMP/MTs baik negeri maupun swasta di kota Mataram. Data pemahaman guru dikumpulkan melalui angket setelah pelatihan dan dianalisis dari 4 aspek yaitu: penerapan K13 dalam pembelajaran IPA, pengetahuan tentang etnosain, penerapan pembelajaran IPA dengan pendekatan etnosain dan penanaman sikap ilmiah dalam pembelajaran IPA. Hasilnya menunjukkan bahwa $66 \%$ guru telah menerapkan K13 dalam pembelajaran IPA, $83 \%$ telah mengenal tentang etnosains, $73 \%$ telah menerapkan pembelajaran dengan pendekatan etnosains, dan $82 \%$ telah menanamkan sikap peduli lingkungan dalam pembelajaran IPA. Pemahaman guru tentang pengembangan perangkat pembelajaran IPA menggunakan pendekatan etnosain sangat baik tetapi implementasinya belum optimal.
\end{abstract}

\section{Korespondensi: yayukmtr@unram.ac.id}

\section{PENDAHULUAN}

Penerapan kurikulum 2013 (K-13) membawa konsekuensi bahwa guru harus semakin berkualitas dalam melaksanaan kegiatan pembelajaran. Kurikulum 13 menekankan penerapan pendekatan saintifik (5M) yang meliputi mengamati, menanya, mengumpulkan informasi, menalar/mengasosiasikan, dan mengomunikasikan serta optimalisasi peran guru dalam melaksanakan pembelajaran abad 21 dan HOTS (Higher Order Thinking Skills). Proses pembelajaran berdasarkan kurikulum 2013 dilaksanakan tidak hanya terjadi di ruang kelas, tetapi juga di lingkungan, sekolah, dan masyarakat karena guru bukan satu-satunya sumber belajar (Permendikbud, 2013). Proses pembelajaran yang diamanatkan K-13 tersebut dapat diwujudkan dengan pembelajaran berbasis etnosains.

Pendekatan etnosains dapat diintegrasikan ke dalam model pembelajaran yang direkomendasikan oleh K-13, seperti: discovery learning, problem based learning (PBL), dan project based learning ( $\mathrm{PjBL}$ ). Implementasi ini menuntut pergeseran model pembelajaran dari pembelajaran berpusat guru ke pembelajaran berpusat peserta didik, dari pembelajaran individual ke arah pembelajaan kolaboratif dan menekankan aplikasi pengetahahuan sains, kreativitas serta pemecahan masalah dalam proses merekonstruksi sains asli (pengetahuan yang berkembang di masyarakat) menjadi sains ilmiah. Snively \& Corsiglia (2001) menyatakan bahwa sains asli berkaitan dengan pengetahuan sains yang diperolehnya melalui budaya di tempat yang sudah lama ditempatinya. Namun, sampai saat ini sains asli yang merupakan subbudaya dari kelompok masyarakat, kurang disadari dan kurang mendapat 
perhatian dari para pakar pendidikan sains maupun guru-guru sains di Indonesia. Baker et al. (1995) menyatakan, bahwa jika pembelajaran sains di sekolah tidak memperhatikan budaya anak, maka konsekuensinya peserta didik akan menolak atau menerima hanya sebagian konsep-konsep sains yang dikembangkan dalam pembelajaran.

Pengintegrasian etnosains ke dalam kurikulum pendidikan sains di sekolah dapat dilakukan dengan mengembangkan perangkat pembelajaran seperti lembar kerja peserta didik (LKPD) dan bahan ajar yang sesuai dengan kondisi daerah sekitar sekolah. Kesempatan ini memberikan ruang bagi dunia pendidikan untuk membantu pemerintah daerah dalam mengoptimalkan potensi daerah terkait potensi etnosains. Tujuannya adalah agar siswa lebih mengenal lingkungan dan daerahnya, yang pada dasarnya punya potensi, serta tidak silau dengan konsep-konsep dari dunia luar. Parris (2010) menyatakan bahwa pembelajaran berbasis etnosains sangat diperlukan bagi peserta didik, karena akan mengajarkan sikap cinta terhadap budaya dan bangsa, dan memperkenalkan kepada peserta didik tentang potensipotensi sebuah daerah sehingga lebih mengenal budaya daerahnya.

Pembelajaran berbasis etnosains yang diintegrasikan ke dalam LKPD dan bahan ajar diharapkan dapat berkontribusi dalam peningkatan pemahaman materi dan pembentukan sikap peserta didik untuk peduli lingkungan. Karakteristik etnosains mengangkat budaya dan kearifan lokal untuk dijadikan sebagai objek pembelajaran sains dapat membuat pembelajaran lebih bermakna. Menurut Prasetyo (2013) keunggulan lokal merupakan ciri khas daerah yang mencakup aspek ekonomi, budaya, teknologi informasi dan komunikasi dan ekologi yang dikembangkan dari potensi daerah. Pengintegrasikan etnosains kedalam pembelajaran akan lebih efektif, jika dimasukkan ke dalam perangkat pembelajaran seperti LKPD dan bahan ajar, karena perangkat pembelajaran menjadi acuan guru dalam menyampaikan materi yang bersifat deklaratif dan prosedural. Materi yang dikembangkan berorientasi pada etnosain. Sementara dalam pelaksanaan pembelajaran dapat menerapkan pendekatan pembelajaran saintifik (scientific Aprroach) melalui model pembelajaran discovery, inquiri, PBL, PjBL, dan KPS (keterampilan proses sains).

Berdasarkan pengamatan dan pengalaman observasi di sekolah-sekolah (SMP) di kota Mataram, perangkat pembelajaran IPA yang dikembangkan oleh guru belum mengintegrasikan pendekatan etnosain, meskipun materi yang mereka ajarkan sudah mengkaitkan dengan kehidupan sehari-hari. Dalam kesempatan ini juga terungkap bahwa masalah yang dihadapi guru dalam mengembangkan perangkat pembelajaran IPA berbasis etnosain antara lain : 1) belum banyak guru yang memahami tentang etnosains, 2) kesulitan mengintegrasikan etnosain ke dalam pembelajaran, 3) adanya kekawatiran guru tentang keefektifan pembelajaran dengan pendekatan etnosain, dan 4) kurangnya pelatihan yang dapat meningkatkan keterampilan guru dalam mengembangkan perangkat pembelajaran IPA berbasis etnosain.

Guru profesional harus mampu mengembangkan persiapan mengajar yang baik, logis, dan sistematis, karena persiapan mengajar yang dikembangkan guru memiliki makna yang cukup mendalam bukan hanya kegiatan rutinitas untuk memenuhi kelengkapan administratif, tetapi merupakan cermin dari pandangan, sikap dan keyakinan profesional guru mengenai apa yang terbaik untuk persiapan mengajar yang matang sebelum melaksanakan pembelajaran, baik persiapan tertulis maupun tidak tertulis. Damayanti, et al (2017) melaporkan bahwa 
model pembelajaran IPA yang mengintegrasikan etnosain dapat meningkatkan hasil belajar serta kemampuan berpikir kreatif siswa, sementara menurut Listianingrum, et al (2017) model pembelajaran inkuiri yang terintegrasi etnosain efektif untuk memberdayakan keterampilan proses sain. Oleh karena itu, dalam rangka meningkatkan profesionalan guru dan menjawab beberapa permasalahan tentang pengembangan perangkat pembelajaran IPA di SMP, ditawarkan solusi berupa kegiatan pelatihan melalui program pengabdian kepada masyarakat yang bertujuan untuk meningkatkan pemahaman guru tentang etnosain dan meningkatkan kemampuan dalam mengembangkan perangkat pembelajaran IPA berbasis pendekatan etnosains pada guru-guru IPA SMP di Kota Mataram.

\section{METODE KEGIATAN}

Metode yang digunakan untuk mencapai tujuan dalam kegiatan pengabdian kepada masyarakat yaitu metode ceramah, diskusi dan tanya jawab untuk meningkatkan pemahaman guru tentang etnosain, dan metode workshop dan FGD untuk meningkatkan keterampilan guru dalam pengembangan perangkat pembelajaran IPA SMP berbasis pendekatan etnosain. Sasaran kegiatan adalah guru-guru IPA dari 20 SMP dan MTs baik negeri maupun swasta yang terdapat di kota Mataram.

Pelaksanaan diawali dengan pengisian angket oleh peserta sebelum kegiatan dimulai yang bertujuan untuk mengetahui pemahaman awal guru sebelum mengikuti kegiatan pelatihan. Pemahaman guru dikaji dari empat aspek yaitu penerapan K13 dalam pembelajaran IPA, pengetahuan tentang etnosain, penerapan pembelajaran IPA dengan pendekatan etnosain dan penanaman sikap peduli lingkungan dalam pembelajaran IPA. Metode ceramah digunakan untuk menyampaikan materi tentang etnosain dalam pembelajaran IPA, pengembangan perangkat pembelajaran IPA, model pembelajaran IPA berbasis etnosain dan contoh perangkat LKPD dan bahan ajar berbasis etnosain, disampaikan oleh narasumber. Diskusi dan tanya jawab berlangsung pada saat penyampaian materi sehingga permasalahan yang dihadapi guru-guru dapat dicarikan solusinya. Perangkat pembelajaran berupa portofolio dihasilkan dari kegiatan workshop yang dilanjutkan dengan presentasi dalam FGD untuk memperoleh tanggapan atau respon dari narasumber dan guru-guru lain peserta workshop sebagai bahan masukan perbaikan perangkat pembelajaran yang telah dikembangkan. Evaluasi dilakukan pada akhir kegiatan melalui pengisian angket untuk mengetahui tingkat pemahaman peserta setelah mengikuti kegiatan pelatihan, Data yang diperoleh selanjutnya dianalisis dan dideskripsikan untuk mendapatkan gambaran tentang kemampuan guru-guru IPA SMP di kota Mataram dan digunakan untuk menarik kesimpulan.

\section{HASIL DAN PEMBAHASAN}

Pembelajaran sains di sekolah, akan lebih mudah dipahami apabila guru memperhatikan budaya yang dimiliki oleh peserta didik (Baker \& Taylor, 1995; Jegede \& Aikendhead, 1999; Michie, 2002; Erinosho, 2013). Pemahaman guru terkait pembelajaran etnosains ini dapat menjadikan pembelajaran sains berlangsung bermakna, sehingga guru memerlukan pemahaman dan kemampuan dalam mengkombinasikan pengetahuan asli di masyarakat dengan pengetahuan ilmiah di sekolah (Sudarmin et al, 2017). Pengintegrasian budaya ke dalam pembelajaran merupakan upaya yang sangat penting untuk dilakukan, 
karena pembelajaran sekolah yang sesuai untuk abad 21 yakni pembelajaran sains yang berpendekatan multicultural (Gunstone, 2014). Melihat kondisi ini, maka peran guru sangat penting, terutama dalam mengembangkan perangkat pembelajaran IPA dengan pendekatan etnosains.

Kegiatan pengabdian dilaksanakan dalam tiga tahap, tahap pertama bertujuan untuk meningkatkan pemahaman guru tentang perangkat pembelajaran berbasis pendekatan etnosains yang disampaikan melalui metode ceramah, diskusi dan tanya jawab, tahap kedua merupakan tahap pengembangan perangkat yang dilakukan di sekolah masing-masing dengan bimbingan tim dan tahap ketiga adalah evaluasi untuk mengkaji pelaksanaan kegiatan pengabdian ini. Kegiatan diikuti 20 orang guru-guru IPA Se-Kota Mataram yang berasal dari SMP Negeri, SMP Swasta dan MTs. Hasil analisis data angket dari peserta pelatihan diberikan dalam bentuk grafik ( Gambar 1), dan terlihat bahwa pemahaman peserta meningkat setelah pelatihan. Peningkatan indikator penerapan K13 dalam pembelajaran IPA (1) sebesar 45\%, indikator pengetahuan etnosains (2) sebesar 67\%, indikator (3) terkait penerapan pembelajaran IPA dengan pendekatan etnosains sebesar $60 \%$, dan indikator (4) penanaman sikap peduli lingkungan dalam pembelajaran IPA sebesar $67 \%$.

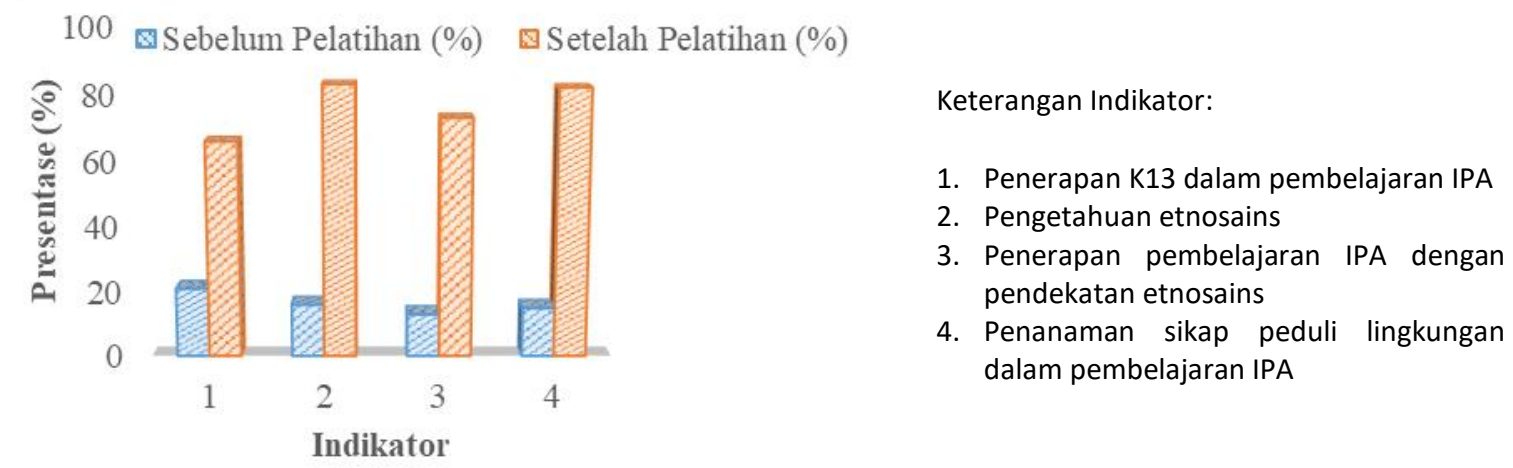

Gambar 1 Profil pemahaman peserta berdasarkan indikator

Pada gambar 1, terlihat bahwa sebelum dilakukannya pelatihan pembelajaran berpendekatan etnosains, persentase keempat indikator tergolong masih sangat rendah. Artinya sebagian besar guru belum mengoptimalkan potensi budaya lokal yang ada dilingkungan peserta didik kedalam perangkat pembelajaran. Peningkatan persentase pemahaman guru pada semua indikator terlihat setelah dilakukan pelatihan dan workshop. Motode pelatihan maupun penyuluhan sering digunakan dalam kegiatan pengabdian kepada masyarakat dan terbukti dapat meningkatkan pengetahuan maupun keterampilan guru-guru terutama dalam pengembangan perangkat pembelajaran (Rachmadi, 2017; Mulyatna dkk, 2018).

Berdasarkan hasil analisis gambar 1 terlihat peningkatan terbesar terjadi pada indikator 2 dan 4 tentang pengenalan etnosains dan menanamkan sikap peduli lingkungan yaitu masing-masing sebesar $67 \%$ dan peningkatan terendah terjadi pada indikator 1 tentang penerapan K13 dalam pembelajaran IPA yaitu sebesar $45 \%$. Peningkatan ini menunjukkan 
adanya respon positif dan peningkatan pemahaman guru tentang pengembangan perangkat pembelajaran IPA SMP dengan pendekatan etnosains yang ditunjukkan dengan peningkatan persentase masing-masing indikator dalam angket yang diberikan setelah kegiatan pelatihan. Selain itu juga keterampilan guru dalam mengembangkan perangkat semakin meningkat terutama dalam mengintegrasikan konsep etnosains dalam RPP sehingga mereka merasa mampu untuk melaksanakan pembelajaran sesuai dengan perangkat yang telah dikembangkan. Hal ini terlihat pada saat diadakan sesi diskusi dan presentasi oleh perwakilan guru-guru IPA ditunjukkan pada gambar 2. Hal ini bertujuan untuk melihat sampai sejauh mana peningkatan pemahaman dan keterampilan mereka dalam mengembangkan perangkat pembelajaran berpendekatan etnosains. Diskusi dan presentasi yang dilakukan berjalan lancar dan terlihat guru sangat antusias dalam menyampaikan hasil diskusi mereka. Salah satu contohnya, pada saat menyampaikan budaya karapan sapi yang dapat dikaitkan dengan KD 3.1 kelas VIII pada materi gerak pada makhluk hidup dan KD 3.2 materi gerak pada benda. Dengan mengangkat satu budaya sudah bisa mengaitkannya dengan beberapa materi, hal ini menunjukkan dengan pemahaman yang telah diperoleh guru maka mereka dengan mudah dapat mengidentifikasi konsep sains ilmiah yang dipadukan. Berikut beberapa foto selama kegiatan berlangsung:
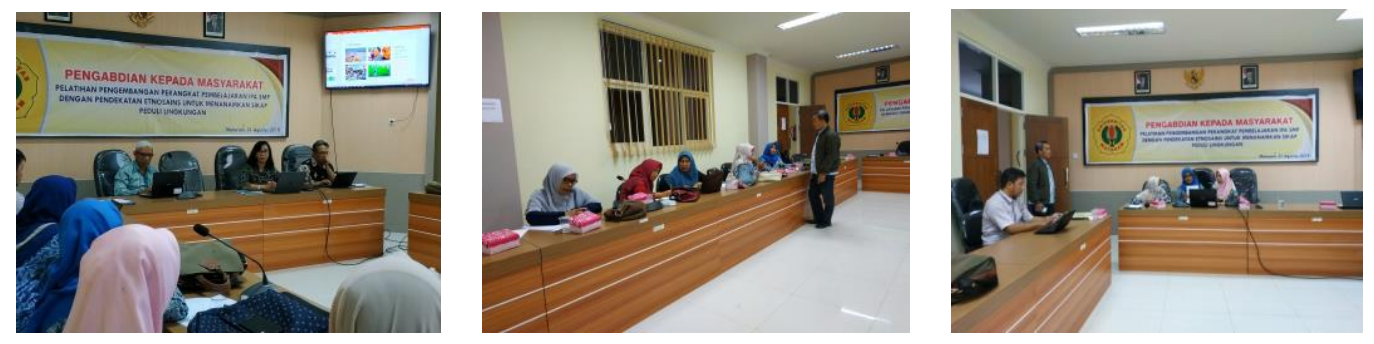

Gambar 2. Kegiatan diskusi dan presentasi peserta pelatihan

\section{KESIMPULAN DAN SARAN}

1) Peningkatan pemahaman guru pada semua indikator terlihat setelah dilakukan pelatihan dan workshop. Persentase peningkatan indikator 1 sebesar $45 \%$, indikator 2 sebesar $67 \%$, indikator 3 sebesar $60 \%$, dan indikator 4 sebesar $67 \%$.

2) Diperoleh peningkatan terbesar terjadi pada indikator 2 dan 4 tentang pengenalan etnosains dan menanamkan sikap peduli lingkungan yaitu masing-masing sebesar 67\% dan peningkatan terendah terjadi pada indikator 1 tentang penerapan K13 dalam pembelajaran IPA yaitu sebesar $45 \%$

3) Hasil pelatihan menunjukkan terjadi peningkatan pemahaman guru tentang etnosain dan peningkatkan kemampuan dalam mengembangkan perangkat pembelajaran IPA berbasis pendekatan etnosains Mataram.

\section{Ucapan Terima Kasih}

Penulis mengucapkan terima kasih kepada Universitas Mataram yang telah memberi dukungan financial serta semua pihak yang telah mendukung kegiatan pengabdian ini. 


\section{DAFTAR PUSTAKA}

Baker, D. \& Taylor, 1995. The effect of culture on the learning of science in non-western countries: the result of and integrated research review. Intenational Journal of Science Education. Vol. 17 (6), 1-16.

Damayanti, C, Ani R, Suharto L. 2017. Pengembangan Model Pembelajaran IPA Terintegrasi Etnosains untuk Meningkatkan Hasil Belajar dan Kemampuan Berpikir Kreatif. Journal of Innovative Science Education. 6 (1): 116-128.

Erinosho, S.Y. (2013). Integrating Indigenous Science with School Science for Enhanced Learning: A Nigerian Example. International Journal for Cross-Disciplinary Subjects in Education (IJCDSE), 4 (2), 1137-1143. Penerapan K13 dalam pembelajaran IPA

Gunstone, A. (2014). Developimg Sustainable Education in Regional Australia. Melbourne : Monash University Publishing.

Jegede, O. \& Aikenhead, G. (1999). Transcending cultural borders: Implications for science teaching. Research In Science And Technology Education, 17 (01), 45-66.

Listianingrum, N., Maridi , Nonoh S.A. 2017. Pengembangan Perangkat Pembelajaran IPA Menggunakan Model Inkuiri Terbimbing Berbasis Literasi Sains Untuk Memberdayakan Ketrampilan Proses Sains. Prosiding Seminar Nasional Pendidikan Sains (SNPS). Surakarta, 26 Oktober 2017.

Michie, M. (2002). Why indigenous science should be included in the school science curriculum. Journal Of Cognition And Culture, 4 (3-4), 409-450.

Mulyatna,F., Farah I., Leny H. Pelatihan Pembuatan Rencana Pelaksanaan Pembelajaran Berdasarkan Kurikulum 2013 DI YAYASAN RAUDLATUL JANNAH. Abdimas Dewantara, 1 (1): 11-22

Parrish, P. 2010. Cultural Dimensions Of Learning: Addressing The Challenges of Multicultural Instruction. International Journal. 11 (2) : 5-32.

Permendikbud. 2013. Struktur Kerangka Kurikulum 2013. Jakarta.

Prasetyo, ZK. 2013. Pembelajaran Sains Berbasis Kearifan Lokal. Prosiding Seminar Nasional Fisika dan Pendidikan Fisika. Surakarta, 14 September 2013.

Rachmadi, D. 2017 Peningkatan Kemampuan Guru Dalam Menyusun Rpp Melalui Pelatihan Di SMA N 1 KARANGRAYUNG. Jurnal Profesi Keguruan. 3 (1): 1-14

Snively, G. and Corsiglia. 2001. Discovering Indigenous Science: Implications for Science Education. Science Education.Vol. 85 (1):7-34.

Sudarmin, Febu, R., Nuswowati, M., \& Sumarni, W. (2017). Development of Ethnoscience Approach in The Module Theme Substance Additive $s$ to Improve the Cognitive Learning Outcome and Student's Entrepreneurship. Journal of Physics: Conference Series, 824, (1). 